\title{
HIGH -PERFORMANCE WORK PRACTICES AND EMPLOYEE ATTITUDES: EVIDENCE FROM HOTEL INDUSTRY IN SRI LANKA
}

\author{
Arumugam Saravanabawan \\ University of Jaffna, Sri Lanka. \\ sujiba2000@yahoo.co.uk
}

\begin{abstract}
In this contemporary world, most of the organizations understand the importance of managing human resources effectively and efficiently to become successful. Many Previous researches have established a significant relationship between High performance Human resource (HR) practices and firm level and individual level outcomes. Few studies have considered the important role of employee perceived HR practices and outcome of high performance HR practices and its mediating roles. To address the recent growing interest in the literature for an investigation of this nature, this study was conducted investigating the relationship between high-performance work practices and employee attitudes in the hotel industry of Sri Lanka. Questionnaire was used to collect the data. Initially discussion was conducted with 200 employees who voluntarily participated in this study from Hotel sector, finally 175 participants agreed to fill out the questionnaire. Of the selected sample 150 questionnaires was complete and usable for this study. Correlation and regression analysis was performed to test the hypothesized relationship. Results of the study showed that high-Performance work practices positively related with intention to remain with organization, further study found positive relationship between employees' perceptions of high-performance work practices and affective commitment; furthermore, study found that affective commitment mediated the relationship between high performance work practices and intention to remain with organization. On the basis of these findings, managerial implications of the study and future research direction were highlighted.
\end{abstract}

Keywords: high- performance work practices, attitudes, commitment, hotel industry, Sri Lanka 


\subsection{Introduction}

Organizations face high competition with their competitors in the contemporary business world. Within unstable and competitive environment, organizations implement effective strategic plans to achieve competitive advantages in a highly competitive environment. Human resource is vital in achieving organizational goals and the contemporary world is aware of this importance. High competition and talents for employee has led to focus on Potential benefits of using high-performance work systems (HPWS) as a means to maximize firms' competitive advantage in the competitive environ-ment (e.g., Sun, Aryee, \& Law, 2007; Guthrie, 2001; Huselid, 1995). Huselid,( 1995) pointed out that human resource practices that strategic human resource management (SHRM) theorists consider performance enhancing are known as high-performance work practices (HPWPs).

Bohlander \& Snell, (2004), define HPWS that a specific combination of Human resource practices (HR practices), work structures, and processes that maximize employee knowledge, skill, commitment, and flexibility. According to Huselid, (1995) and Pfeffer, (1998) high-performance work systems (HPWS) referred to intercon- nected human resource management practices, including comprehensive recruitment and selec-tion procedures, incentive compensa-tion and performance management systems, flexible work arrangements and extensive employee involvement and training, which are designed to enhance employee and firm performa-nce out-comes through improving work-force competence, attitudes, and motivation.

Most of the strategic human resource management (SHRM) theory emphasized that these practices increase employees' knowledge, skills, and abilities (KSAs), empower employees to leverage their KSAs for organizational benefit, and increase their motivation (Becker \& Huselid, 1998; Delery \& Shaw, 2001). Thus the result is greater job satisfaction, lower employee turnover, higher productivity, and better decision making. Many previous HR researches (Lawler, 1992; 1996; Levine, 1995; Pfeffer, 1998) has studied on high-performance work systems, a term used to denote a system of HR practices designed to enhance employees' skills, commitment, and productivity in such a way that employees become a source of sustainable competitive advantage.

The hotel industry that selected in this research was chosen precisely because Sri Lanka is known as the pearl of the 
Indian Ocean and also very popular destination for tourists. The country is blessed with the placement, the natural beauty and the culture which would be the key features for a destination to have successful and a thriving tourism industry (Sri Lanka tourism development authority, 2011).Tourism is the fourth biggest foreign income earning sector in the country behind the labor remittances, apparel exports and tea export (Annual report central bank of Sri Lanka, 2011). Thus HR practices designed to enhance employees' skills, commitment, and productivity, intention to remain with organization in such a way that employees become a source of sustainable competitive advantage in the tourism industry is vital for the success.

Many previous authors (e.g., Huselid, 1995; Wright, McCormick, Sherman, \& McMahan, 1999; Wright, McMahan, \& McWilliams, 1994; Bowen \& Ostroff, 2004; Nishii, Lepak, \& Schneider, 2008; Kehoe \& Wright, 2013) have studied the association between HR practices and outcomes and they have congregated in their belief that HR practices are associated with organizational outcomes throughout their influence on employee attitudes and behaviors. However, the assumption that human resource management (HRM) systems impact employees' attitudes and behaviors, as well as firm performance, through various social processes has remained largely untested Takeuchi, Chen \& Lepak, (2009).

The recent empirical investigations on high performance HR practices to employee outcomes are consistent with previous SHRM research and they made valuable contribution to our understanding of the initial steps of the HRperformance causal relationship. However additional work is still needed to assess the role of employees' perceptions of HR practices in determining their attitudinal and behavioral outcomes (Nishii \& Wright, 2008); for a recent empirical article examining outcomes of employees' attributions of HR practices, (see Nishii, Lepak, \& Schneider, 2008).

In light of these extant research needs, this study extends to what extent existing conceptualization of high performance HR practices or system to employee attitudes are adequate in Sri Lankan context in the post war context, where Tourism industry make considerable contribution to the economy and adopting High performance work system are emerging in the post war context. Thus, the objectives of this study are examining the relationship between employees' perceptions of high-performance HR practice and how 
it will impact on their attitudinal (such as affective commitment). From here, researcher present theoretical model, and discuss the employed methodology in testing the predictions, and report the empirical results. Finally, researcher concludes by discussing the implications of the research findings and by proposing possible directions for future research in this vein.

\subsection{Theory and Hypotheses}

Human resource is the most important asset in a service organization than manufacturing organization (Boselie \& wiele, 2002) and strategic human resource management "the pattern of planned human resource deployments and activities that are intended to enable an organization to achieve its goals" (Wright \& McMahan, 1992, p. 298).

Most of the previous strategic HRM literature (Huselid, 1995; Lepak et al., 2006; Lepak \& Snell, 2002) confirms in such way that the concept of high performance works systems (HPWS) has emerged as a core construct encompassing the extent to which firms invest in the attraction, selection, management, and retention of the best possible human capital. Takeuchi, Chen \& Lepak, (2009) conclude that HPWS are indicative of the value firms place on their human capital as a source for competitive advantage, with higher HPWS levels indicative of greater value firms place in their human capital.

According to behavioral perspective, the firms rely on HR practices, such as HPWS, to elicit and control certain employee role behaviors and attitudes (Jackson et al., 1989). However, the relationships between HPWS and employee-level outcomes may not be direct Takeuchi, Chen, \& Lepak, (2009) Delery \& Shaw (2001) in their study state that there is growing acceptance of the resource-based view as the main rationale for the link between human resource management practices and firm performance. There is general agreement that: (1) human capital can be a source of competitive advantage, (2) that HRM practices are the most direct influence on the human capital of a firm, and (3) that the complex nature of a coherent HRM system of practices can enhance. Further they state at least two major features distinguish SHRM research from the more traditional HR management (HRM) practice research. First, SHRM studies have focused on explicating the strategic role that HR can play in enhancing organizational effectiveness. A second distinguishing feature is the level of analysis. HRM practice research has traditionally had an individual-level focus; in contrast, SHRM research is typically conducted 
at the business-unit or organizational level of analysis. Reflecting this direction, recent HR research has focused on high-performance work systems, a term used to denote a system of HR practices designed to enhance employees' skills, commitment, and productivity (Lawler, 1992; 1996; Levine, 1995; Pfeffer, 1998).

Although recent studies have considered various employee attitudinal and behavioral outcomes of high-performance HR systems, research remains scarce explicitly examining, in the same study, the impact of HR practices on both these outcomes. Thus, the causal sequence by which high-performance HR practices are likely to affect key employee attitudes and then employee behaviors requires further theoretical and empirical attention. Specifically, this study consider the attitudinal outcome of affective organizational commitment and the behavioral (or behavior-oriented) outcomes of intent to remain with the organization, for a number of reasons-namely, their relevance, importance, and generalizability (Kehoe \& Wright, 2013).

First, high-performance HR systems rely on the creation of a mutual investment based employment relationship, wherein an organization invests in workforce skills and opportunities and, in turn, expects employees to be qualified and motivated to make valuable work-related investments in the organization (Huselid, 1995). Affective commitment reflects a likely attitudinal consequence of this type of positive mutual social exchange from the perspective of an employee. Organizational citizenship behaviors, intent to remain with the organization, and attendance at work (the opposite of absenteeism) likely represent behavioral manifestations of emplo-yees' affective commitment to the organization, thereby suggesting relevance of these outcomes to a high-performance HR approach (Kehoe \& Wright, 2013). As suggested by (Meyer and Alan, 1990; 1991), affective organizational commitment or emotional attachment to an organization and continue organizational commitment, or tendency to maintain organizational membership because of the perceived high cost of discontinuing membership were included in the present study.

\subsection{High-Performance HR Pra ctices and Affective Commi tment}

Three-component model of organizational commitment (Allen \& Meyer, 1990) conceptualizes commitment in three dimensions: such as affective, normative, and continuance commit-ment. Three-component model has been 
supported by factor analyses (cf. Meyer, et al., 2002) and study confirmed that the three components relate differently to various antecedents and consequences. According to the model of organizational commitment, which was developed by Meyer and Allen, (1990; 1991) refers affective commitment, in such way that the affective component refers to employees - emotional attach-ment to, identification with, and involvement in the organization.

For the purpose of this study, researcher focuses on affective commitment-or positive affection toward the organization, as reflected in a desire to see the organization succeed in its goals and a feeling of pride at being part of the organization (Cohen, 2003)-and consistent with previous research (Kehoe and Wright, 2013; Meyer et al., 2002) researcher focuses affective commitment for several reasons. First, affective commitment has been shown to be affected by employees' work and organizational experiences. Second, As pointed out by Meyer et al., (2002), affective commitment has been demonstrated to relate strongly and consis-tently to desired work outcomes, (such as low absenteeism and organizational citizenship behaviors) and its role as a key linking mechanism between highperformance HR practices and higher level performance outcomes has been supported by previous research, (e.g., Gong et al., 2009).

As suggested by social exchange theory, individuals are drawn to participate and invest in rewarding relationships, after which they become bound to return benefits or favors to their partners in exchange (Blau, 1983). Thus if highperformance HR practices, are implemented effectively, that are likely to cause employees to perceive that their exchange relationship with the organization is characterized by a supportive environment based on investments in employee skills, regular unbiased performance feedback, availability of fair and attractive rewards for performance- including compen-sation and advancement opportu-nities-and mutual efforts toward meaningful goals (Kehoe \& Wright, 2010) This in return, as pointed out by Cohen, (2003) employees are likely to feel an obliga-tion to the organization's goals and so develop an affective bond with the organization itself- which may be exp-ressed as affective commitment. Thus for this study researcher postulate that

Hypothesis1: Employees' perceptions of high-performance HR practice will be positively related to affective commitment.

High-Performance HR Practices and Intent to remain with the organization 
Many previous studies (Batt, 2002; Guthrie, 2001; Huselid, 1995) have been empirically linked high performance HR practices to retention and turnover. However, (e.g., Sun et al., 2007) pointed out that the underlying mechanisms of this relationship remain uncertain. Sun et al., (2007) relying on social exchange theory, examined service-oriented organizational citizenship behavior as a mediator of the high-performance HR-turnover relationship. However, the authors' explanation relied less on the organizational citizenship behaviors and more on employees' affective attachments that led to these behaviors. Thus, relying again on the social exchange perspective, we argue that affective commitment better explains (indirectly) the relationship between high-performance HR practices and employees' intent to remain with the organization (Kehoe \& Wright, 2013).

Boyle et al., (1999) in their study they reported that job satisfaction had the strongest influence on intent to remain employed but also that nurse-manager leadership style directly influenced nurse intent to stay. Job stress, autonomy and group cohesion indirectly influenced nurse intent to remain employed through job satisfaction. Sourdif, (2004) hypothesized that nurse intent to stay was influenced by satisfaction at work, satisfaction with administration, organizational com-mitment, and work group cohesion. Further, Sourdif found that work satisfaction and satisfaction with administration were the most significant predictors of intent to remain and explained $25.5 \%$ of variance in intent to remain. Thus HR Practices which implemented in the organization effectively may lead for satisfaction with work and administration and induce the commitment of the employees. Previous researchers Blau, (1983); Cohen, (2003) also confirm this such a way that effectively committed employees under a highperformance HR system are likely to hold deep bonds with the organization and feel both eager and obliged to contribute to organiza-tional goals. Kehoe and Wright, (2013) in their study indicate and argue that they are likely to express an intent to remain that is greater than that of less committed employees, for a few rea-sons. that are, employees can contribute to organizational effectiveness only as they continue their employment relationship; so, a desire to help achieve organizational goals aligns with intent to remain with the organization and employees are likely to choose to leave an organization when they think that incentives to stay no longer match the contributions they make (March \& Simon,1958). The desire to leave from the organization thus represents a form of withdrawal (Sheridan, 1985) and likely reflects a lack of emotional 
attachment to the organization and its goals (Kehoe, and Wright, 2013). Labatmediene, Endriulaitiene, \& Gustainiene, (2007) in their study concluded that more committed employees are less intended to leave the organization than less committed employees. Further, Stallworth, (2003) in his study states that affective commitment is the most important predictor of intention to leave. Thus researcher made the conclusion that more committed employees are less intended to leave the organization.

Thus, from the above literature and empirical support for a significant relationship between affective commitment and both intent to remain and turnover (e.g., Angle \& Perry, 1981; Mayer \& Schoorman, 1992; Ostroff, 1992; for a related meta analysis, see Harter, Schmidt, \& Hayes, 2002) researcher postulate based on the perceived obligations and affective attachments of committed employees in the high-performance HR context,

Hypothesis 2a $\left(\mathbf{H}_{2 \mathrm{a}}\right)$ : Employees' perce-ptions of high-performance HR practice will be positively related to intention to remain with the organization.

Hypothesis 2b $\left(\mathbf{H}_{2 b}\right)$ : Affective commitment will mediate the positive relationship between high-performance
HR practice perceptions and intent to remain with the organization.

\subsection{Measures}

\section{Employee-level measure of HPWS}

The main focus of this research is designed to assess the effects of HPWS on employee-level outcomes, recent studies, Jensen, Patel, \& Messersmith, (2013) and Huselid \& Becker, (2011) assessed the effects of HPWS on individual employees. This research work focused to examine the individuallevel perceptions of employees in the context of HPWS. To measure employee perceptions of HPWS, a 15item scale was utilized. The scale consisted of (a) $7 \mathrm{HR}$ practice items drawn from Gould-Williams and Davies (2005) and (b) 8 items from Truss (1999), consistent with content reflecting employee skills, motivation, and empowerment. Recently, Jensen, Patel, \& Messersmith, (2013) has used these scale for their study. Employees were asked to indicate on a 7-point scale $(1=$ strongly disagree to 7 = strongly agree) the extent to which they agreed or disagreed that each practice was being utilized. The sample items included in this study were "I am provided with sufficient opportunities for training and development"; a rigorous selection process is used to select new recruits"; the rewards I receive are directly related 
to my performance at work." And the appraisal system provides me with an accurate assessment of my strengths and weaknesses". Scale reliability $\alpha$ for these items for this study was .82 .

\section{Affective commitment Scale}

Affective commitment was measured through a scale developed using five items that were consistent with items used in previous research (e.g., Meyer \& Allen, 1997 Allen \& Meyer 1990). The sample item included in this study for affective commitment was "I feel a strong sense of belonging to this organization" and "I am willing to work harder to help this company succeed and "I am proud to work for this organization". Respondents were asked to report, on a five point likert scale ranging from 1(strongly disagree) to 5 (strongly agree) with each commitment statement; we then computed a mean commitment scale for each individual by averaging the individual's responses to the five commitment items as computed by Kehoe, \& Wright, 2013. Internal consistency reliability of these items for this study was $(\alpha=.83)$.

\section{Intent to remain with the organi- zation Scale}

Intent to remain with the organization was measured by using four items scale developed by Kehoe \& Wright, (2013) respondents were asked to indicate, on scale ranging from 1 (strongly disagree) to 5 (strongly agree) with each statement. Sample representative items included "I plan to spend my career at this organization" and "I intend to stay at this organization for at least the next 12 months." and "I do not plan to look for a job outside of this company in the next 6 months" Item scores were again averaged at the individual level to calculate a single "intent to remain" scale as computed by Kehoe \& Wright, (2013). Cronbach's $\alpha$ for these items for this study at the individual level was .86 . Control Variables

The selection of control variables was guided by previous studies (e.g., Kehoe \& Wright, 2013; Bolino \& Turnley, 2005; Lundberg \& Frankenhaeuser, 1999; Nishii et al., 2008; Takeuchi et al., 2007). At the employee level, researcher controlled for job position, employment status, and gender, Level of education; age; marital status and years of Experience. By including these factors, Researcher control for the potential effects of individual demographic differences, such as level of education and tenure, which might affect the way an individual, perceives commitment, intention to remain with organization. For instance, Nishii et al., (2008) note that long-tenured employees are less likely to have favorable views of the HR system; therefore, this is an important 
factor to control for in our model. Furthermore, Kehoe \& Wright, (2013) they controlled for job category, because different types of jobs vary in their relative desirability and likelihood of attracting committed, motivated, and diligent employees.

\subsection{Results and discussion}

The following section deals with main characteristics of sample, descriptive statistics of studied variables, corre lation and hierarchical regression analyses to test the hypotheses.

\section{Table 1: The Main Characteristics of the Sample}

\begin{tabular}{|l|c|c|}
\hline Characteristics & Frequency & percent \\
\hline Gender & & 70.0 \\
\hline Male & 105 & 30.0 \\
\hline Female & 45 & \\
\hline Marital status & 82 & 54.7 \\
\hline Married & 68 & 45.3 \\
\hline Unmarried & & \\
\hline Age group & 16 & 10.7 \\
\hline $15-20$ & 42 & 28.0 \\
\hline $21-30$ & 50 & 33.3 \\
\hline $31-40$ & 33 & 22.0 \\
\hline $41-50$ & 9 & 6.0 \\
\hline Above-50 & & \\
\hline Educational Qualification & 77 & 51.3 \\
\hline GCEO/L & 30 & 20.0 \\
\hline GCEA/L & 21 & 14.0 \\
\hline Diploma & 12 & 6.0 \\
\hline Bachelors Degree & 10 & 6.7 \\
\hline Post Graduate Degree & & 28.0 \\
\hline Experience & 42 & 34.0 \\
\hline Below 1 Year & 51 & 18.0 \\
\hline 1-3 Years & 27 & \\
\hline 3-5 Years & & \\
\hline $5-7$ Years & 24 & \\
\hline Above 7 Years & & \\
\hline
\end{tabular}

Note: $N=150$; Source: Survey data 
Means, standard deviations, and correlation coefficients for all measures at individual level are reported in the following tables

\section{Table 2: Descriptive Statistics of studied variables (at Individual level)}

\begin{tabular}{|l|c|c|c|c|c|}
\hline Variables & $\mathrm{N}$ & Minimum & Maximum & Mean & Std. Deviation \\
\hline High Performance work system & 150 & 1.00 & 5.00 & 3.76 & .61 \\
\hline Affective Commitment & 150 & 1.00 & 5.00 & 4.31 & .67 \\
\hline Intention to remain with organization & 150 & 1.00 & 5.00 & 3.83 & .84 \\
\hline
\end{tabular}

Source: Survey data

Correlation analyses of hypotheses are reported in Table 3. Our first two hypotheses predicted that employees' perceptions of high-performance HR practice would positively relate to affective commitment (Hypothesis 1) and intention to remain with organization (Hypothesis 2a). Supporting
Hypotheses 1 and 2a, employees' perceptions of high-performance HR practice would positively related to affective commitment $(\beta=.66, \mathrm{p}<.000)$, and intention to remain with organization $(\beta=.68, \mathrm{p}<.000)$. Thus the hypotheses $\mathrm{H}_{1}$ and $\mathrm{H}_{2 \mathrm{a}}$ are supported.

\section{Table 3: Correlation matrix of the studied variables at Individual level}

\begin{tabular}{|l|c|c|c|}
\hline Variables & 1 & 2 & 3 \\
\hline 1.High Performance work system & 1 & & \\
\hline 2.Affective Commitment & $.66^{* *}$ & 1 & \\
\hline 3.Intention to remain with organization & $.68^{* *}$ & $.75^{* *}$ & 1 \\
\hline
\end{tabular}

** Correlation is significant at the 0.01 level (2-tailed). 
Testing the Mediating Role of Affective Commitment on Intention to remain with organization

To conclude that one variable (affective commitment) mediates the relationship between an independent variable (High Performance work practices) and a dependent variable (Intention to remain with organization), it is necessary to show that: high performance work practices significantly affects intention to remain with organization; high performance work practices significantly affects affective commit ment and when intention to remain with organization is regressed on both high performance work practices and affective commitment, affective commitment must be significant and high performance work practices must not be significant ( e.g. see Shafer \& Simmons, 2008).

\section{Table 4: Summary of Regression Analysis Affective Commitment as Mediator}

\begin{tabular}{|c|c|c|c|}
\hline Independent variable & $\begin{array}{c}\text { Model 1: } \\
\text { Intention to remain } \\
\text { with organization } \\
\end{array}$ & $\begin{array}{c}\text { Model 2: } \\
\text { Affective } \\
\text { commitment }\end{array}$ & \begin{tabular}{|c|} 
Model 3: \\
Intention to remain \\
with organization \\
\end{tabular} \\
\hline \multicolumn{4}{|l|}{ Step 1: Control Variables } \\
\hline Year of experience & .00 & .02 & .00 \\
\hline Level of Education & .01 & .17 & -.01 \\
\hline \multicolumn{4}{|l|}{ Independent variable } \\
\hline HPWS & $.68^{* *}$ & $.66^{* *}$ & $.68^{* *}$ \\
\hline$\Delta \mathrm{R} 2$ & .13 & $.27 * *$ & .13 \\
\hline \multicolumn{4}{|l|}{ Step-2 : Control Variables } \\
\hline Year of experience & .00 & .04 & .04 \\
\hline Level of Education & -.07 & .13 & -.02 \\
\hline \multicolumn{4}{|l|}{ Independent variable } \\
\hline HPWS & .16 & $.48^{* *}$ & .19 \\
\hline$\Delta \mathrm{R} 2$ & $.09^{* *}$ & $.09 * *$ & $.19^{* *}$ \\
\hline \multicolumn{4}{|l|}{ Step-3: Control Variables } \\
\hline Year of experience & & & .03 \\
\hline Level of Education & & & -.05 \\
\hline \multicolumn{4}{|l|}{ Independent variable } \\
\hline HPWS & & & .11 \\
\hline Mediator: Affective Commitment & $.35 * *$ & - & $.22^{*}$ \\
\hline$\Delta \mathrm{R} 2$ & & & $.03^{*}$ \\
\hline R2 for total equation & $.22 *$ & $.36^{* *}$ & $.36^{*}$ \\
\hline
\end{tabular}


In this study, to test the hypothesis $\mathrm{H}_{2 b}$; Affective commitment mediates the relationship between high performance work practices and Intention to remain with organization; high performance work system significantly affects intention to remain with organization ( $\beta=.68, \Delta \mathrm{R}^{2} \quad$ value of $0.13, \mathrm{p}<.000$, see above model 1 in table 4 ), high performance work practices signifi-cantly affects affective commitment $(\beta=.66$, $\Delta \mathrm{R}^{2}$ value of $0.27, \mathrm{p}<.000$, see above model 2 in table 4), and when Intention to remain with organization is regressed on both High Performance work system and affective commitment, affective commitment is significant $\left(\beta=.22, \Delta \mathrm{R}^{2}\right.$ value of $0.03, \mathrm{p}<.05$, see above model 3 in table 4 ), and high performance work practices is not significant $(\beta=$ $.11, \Delta \mathrm{R}^{2} \quad$ value of $0.03, \mathrm{p}>.0 .05$, see above model 3 in table 4 ). This result confirms that affective commitment mediate the relationship between high performance work practices and intention to remain with organization thereby supporting hypothesis $\mathrm{H}_{2 b}$.

\subsection{Discussion, implications and Conclusion}

The findings of previous studies show that there is a relationship between high performance (HR) work practices and intention to remain with organization; however, the studies under literature review are from different environments, different sectors and different countries. Considering the Sri Lankan context, finding of this study will give more generalizable insights about importance of high performance work practices to remain employees with organization. Also this study will give insights to what extent the way leaders practicing the high performance work practices will have impact on employees' intention to remain within organization and which type of HR Practices should be managed effectively to have commitment and retain people in organizations. No specific studies have done in the past on this issue in Sri Lankan context.

This study is consistent with the study of Kehoe \& Wright (2013). They developed and tested a model based on social exchange theory in which affective commitment Affective commitment completely mediates the relationship between HR practice perceptions and intent to remain with the organization. Employees' collective perceptions of high-performance HR practice use are positively related to affective commitment, organizational citizenship behavior, and intent to remain with the organization. Also our study consistent with the previous study that HPWS was positively related to individual affective commitment (Nishii, Lepak, \& Schneider, 2008) 
Our findings also support our predictions: High-performance HR practice perception is positively related to affective commitment, and intent to remain with the organization. Furthermore, affective commitment completely mediates the relationship between high-performance HR practice perceptions and intent to remain with the organization. In particular, affective commitment mediates the impact of HR practice perceptions on individual-level intent to remain with the organization.

Previous researchers called for little work theoretically and empirically to address the role of attitudes in creating the context necessary for desirable behaviors to consistently emerge from the implementation of a high-performance HR system in the organizations. Thus, based on the social exchange theory, our findings consistent and suggest that employees' perceptions of High-performance HR practices likely affect employees' behaviors to at least some extent through their effect on an important attitudinal outcome-that is, affective commit-ment (see Kehoe \& Wright, 2013).

Thus, Organizational HR Practices and its antecedents or consequences become an important research issue in Sri Lankan Hotel industry as it is emerging sector in the economy of the country. Especially, useful might be to know the relationship between high performance HR practices and intention to remain with organization. As turnover intentions (opposite to intention to remain with organization) often lead to the leave from the organization, it is possible to suggest to employers to increase the High performance HR practices in order to keep employee retention stable in the organization. The research results may be useful for Sri Lankan Context where Organizations face various difficulties when there is a high labor Turnover Island wide, retention of operational level employees has been of serious concern to managers in the face of ever increasing high rate of employee turnover in Sri Lanka (Rathnasooriya \& Lakmini, 2016). So the results of this study could make the contribution to solving this problem.

This is the practical issue of concern to Sri Lankan organizations. The turnover is always costly to the organizations given the large investment made in selection, training and development of personnel and even in organizational culture.

Future research direction and limitations The present study examined the relationship between High performance HR practices and intention to remain with organization of Hotel industry. Future research should include other 
possible industries in the high performance HR practices and intention to remain with organization research. Second, the present study is a crosssectional in nature, thus data were collected at one point in time. Therefore, longitudinal or experimental designs are required to confirm the causality of the hypothesized relationships in this context. Third, another limitation of the present study is that individual perceived values (relied on self-reported questionnaire data) were taken into the consideration, so the unit level and team level data not collected. Therefore, it is difficult to generalize the results of the study, and findings cannot be applied to other situations. Fourth, the study was conducted with a small sample in a hotel industry that may be not representative, so one should be careful to make generalizations to other populations. Future study should employ a larger sample size that would help in the strength of the findings, especially in all industries in Sri Lanka.

Lok \& Crawford (2001) argued that various cultural dimensions can affect the commitment outcome of individuals in organizations. Thus cross crosscultural comparisons should include in the future research, especially where people are said to be individualist and collectivistic in nature. Finally, as suggested by Kehoe \& Wright (2013) this study did not empirically examine the antecedents of variability in employees' perceptions of HR practices. Thus empirical work is needed examining the relative significance of potential antecedents in the Strategic human Resource management context.

\section{References}

Allen, N.J. \& Meyer, J.P. (1990). The measurement and antecedents of affective, continuance, and normative commitment to the organization. Journal of Occupational Psychology, 63, 1-18.

Angle, H.L., \& Perry, J.L. (1981). An empirical assessment of organizational commitment and organizational effectiveness. Administrative Science Quarterly, 21, 1-14.

Annual Statistical Report (2014) Sri Lanka Tourism Development Authority ASR http://www.sltda.lk/sites/default/files/Annual_Statistical_Report-2014.pdf

Annual Report Central Bank of Sri Lanka, (2011) https://www. parliament.lk /papers_presented/09052012/central_bank_annual_report_2011.pdfBatt, R. (2002). Managing customer services: Human resource practices, quit rates, and sales growth. Academy of Management Journal, 45: 587-597. 
Becker, B. E., \& Huselid, M. A. (1998). High performance work systems and firm performance: A synthesis of research and managerial implications. In. K. M. Rowland \& G. R. Ferris (Eds.), Research in personnel and human resource management:53-101.Greenwich, CT: JAI Press.

Blau, P. M. 1983. On the nature of organizations. Malabar, FL: Krieger.

Bohlander. G., and Snell, S., (2004), Managing Human Resources, International student edition, 13e, Thmson South -Western, PP, 369, 370.

Bolino, M. C., \& Turnley, W. H. (2005). The personal costs of citizenship behavior: the relationship between individual initiative and role overload, job stress, and workfamily conflict. Journal of Applied Psychology, 90(4), 740.

Bowen D.E, OstroffC. (2004). Understanding HRM-firm performance linkages: The role of the "strength" of the HRM system. Academy of Management Review, 29(2), 203-221.

Boyle D.K, Bott M.J, Hansen HE, Woods CQ, Taunton RL. (1999).Managers' leadership and critical care nurses' intent to stay. American Journal of Critical Care. $8(6): 361-371$.

Cohen, A. (2003). Multiple commitments in the workplace an integrative approach. Mahwah, N.J: Erlbaum.

Delery J.E, Shaw J.D. (2001). The strategic management of people in work organizations: Review, synthesis, and extension. In Ferris GR (Ed.), Research in per-sonnel andhuman resources management, Vol. 20 (pp. 165-197). New York: JAI Press.

Delery, J. E., \& Shaw, J. D. (2001). The strategic management of people in work organizations: Review, synthesis and extension. In K. M. Rowland \& G. R. Ferris (Eds). Research in personnel and human resourcemanagement:165-197. Greenwich, CT: JAI Press.

Gong, Y., Law, K. S., Chang, S., \& Xin, K. R. 2009. Human resource management and firm performance in China: The different role of managerial affective and continuance commitment. Journal of Applied Psychology, 94: 263-275.

Gould-Williams, J. S., and Davies, F. (2005). Using social exchange theory to predict the effects of HRM practice on employee outcomes: An analysis of public sector workers. Public Management Review, 7(1), 25-47.

Guthrie, J. P. (2001). High-involvement work practices, turnover, and productivity: Evidence from New Zealand. Academy of Management Journal, 44: 180-190.

Guthrie, J. P. (2001). High-involvement work practices, turnover, and productivity: Evidence from New Zealand. Academy of Management Journal, 44: 180-190.

Harter, J. K., Schmidt, F. L., \& Hayes, T. L. (2002). Business-unit-level relationship between employee satisfaction, employee engagement, and business outcomes: a meta-analysis. Journal of Applied Psychology, Vol. 87, No. 2, 268-279 
Huselid MA. (1995). The impact of human resource management practices on turnover, productivity, and corporate financial performance. Academy of Management Journal,38, 635-672.

Huselid, M.A., \& Becker, B.E. (2011). Bridging Micro and Macro Domains: Workforce Differentiation and Strategic Human Resource Management. Journal of Management, Vol. 37 No. 2, 421-428.

Jackson SE, Schuler RS, Rivero JC. (1989). Organizational characteristics as predictors of personnel practices. Personnel Psychology, 42, 727-786.

Jensen, J. M., Patel, P. C., \& Messersmith, J. G. (2013). High performance work systems and job control: Consequences for anxiety, role overload, and turnover intentions. Journal of Management, 39, 1699-1724.

Jensen, J.M. Patel, P.C. and Messersmith,J.G. (2013) High-Performance Work Systems and Job Control: Consequences for Anxiety, Journal of Management Vol. 39 No. 6, 1699-1724. DOI: $10.1177 / 0149206311419663$.

Kehoe, R.R. and Wright, P. M. (2013).The Impact of High-Performance Human Resource Practices on Employees' Attitudes and Behaviors Journal of Management 2013 39: 366. DOI: $10.1177 / 0149206310365901$

Lawler, E. (1992). The ultimate advantage: Creating the high-involvement organization. San Francisco: Jossey-Bass.

Levine, D. (1995). Reinventing the workplace: How business and employers can both win. Washington, DC:Brookings Institution.

LepakD. P and .Snell,S.A, (2002). Examining the Human Resource Architecture: The Relationships among Human Capital, Employment, and Human Resource Configurations. Journal of Management, Volume 28, Issue 4, August, Pages 517-543

Lina Labatmediene, Aukse Endriulaitiene, Loreta Gustainiene, (2007) "Individual correlates of organizational commitment and intention to leave the organization", Baltic Journal of Management, Vol. 2 Issue: 2, pp.196-212, doi: 10.1108/ 17465260710750991

Lok, P. Crawford,J. (2001) "Antecedents of organizational commitment and the mediating role of job satisfaction", Journal of Managerial Psychology, Vol. 16 Issue: 8, pp.594-613, https://doi.org/10.1108/EUM0000000006302

Lundberg, U., \& Frankenhaeuser, M. (1999). Stress and workload of men and women in high-ranking positions. Journal of occupational health psychology, 4(2), 142.

March, J. G., \& Simon, H. A. (1958). Organizations. New York: Wiley.

Mayer, R., \& Schoorman, F. (1992). Predicting Participation and Production Outcomes through a Two-Dimensional Model of Organizational Commitment. The Academy of Management Journal,35(3), 671-684. Retrieved from http://www.jstor. org/stable/256492 
Meyer, J. P. and Allen, N.J. (1991). A Three-Component Conceptualization of Organizational Commitment, Human Resource management Review 1, 61-89.

Meyer, J. P., \& Allen, N. J. (1997). Commitment in the workplace: Theory, research, and application. Thousand Oaks, CA: Sage.

Meyer, J. P., Stanley, D. J., Herscovitch, L., \& Topolnytsky, L. 2002. Affective, continuance, and normative commitment to the organization: A meta-analysis of antecedents, correlates, and consequences. Journal of VocationalBehavior, 61: 2052.

Nishii, L. H., \& Wright, P. M. (2008). Variability within organizations: Implications for strategic human resources management. In D. B. Smith (Ed.), The people make the place: Dynamic linkages between individuals andorganizations (pp. 225-248). Mahwah, NJ: Erlbaum.

Nishii, L. H., Lepak, D. P., \& Schneider, B. 2008. Employee attributions of the "why" of HR practices: Their effects on employee attitudes and behaviors, and customer satisfaction. Personnel Psychology, 61: 503-545

Ostroff, C. (1992). The relationship between satisfaction, attitudes, and performance: An organizational level analysis. Journal of Applied Psychology, 77: 963.

Boselie, P. and Wiele,T. (2002). "Employee perceptions of HRM and TQM, and the effects on satisfaction and intention to leave", Managing Service Quality: An International Journal, Vol. 12 Issue: 3, pp.165-172, https://doi.org/ 10.1108/09604520210429231

Pfeffer J. (1998). Seven practices of successful organizations. California Management Review, 40, 96-124.

Pfeffer, J. (1998). The human equation: Building profits by putting people first, Boston: Harvard BusinessSchool Press.

Rathnasooriya, S.K. Lakmini, V.K. J (2016). Impact of Job Related Factors on Turn over Intention of Operational Level Employees in Apparel Industry in Sri Lanka IOSR Journal of Business and Management (IOSR-JBM) e-ISSN: 2278-487X, p-ISSN: 2319-7668. Volume 18, Issue 12. Ver. III (December. PP 39-46.

Shafer, W. E., Simmons, R.S., (2008). Social responsibility, Machiavellianism and tax avoidance: A study of Hong Kong tax professionals, Accounting, Auditing \& Accountability Journal, Vol. 21 No. 5, pp. 695-720DOI 10.1108/095135708108 72978.

Sheridan, J. E. (1985). A catastrophe model of employee withdrawal leading to low job performance, high absenteeism, and job turnover during the first year of employment. Academy of Management Journal, 28: 83.

Sourdif J. (2004) Predictors of nurses' intent to stay at work in a university health center. 
6:59-68.

Stallworth, H.L. (2003), Mentoring, organizational commitment and intentions to leave public accounting. Managerial Auditing Journal 18(5), 405-419.

Sri Lanka Tourism Development Authority Statistical Report (2011) http://www.sltda.lk/sites/default/files/Annual_Statistical_Report-2011.pdf

Sun, L., Aryee, S., \& Law, K. S. (2007). High-performance human resource practices, citizenship behavior, and organizational performance: A relational perspective. Academy of Management Journal, 5: 558-577.

Takeuchi, R. Chen, G. and Lepak, D.P. (2009).through the looking glass of a social system: cross-level effects of high-performance work systems on employees' attitudes Personnel psychology, 62, 1-29

Takeuchi, R., Lepak, D. P., Wang, H., \& Takeuchi, K. (2007). An empirical examination of the mechanisms mediating between high-performance work systems and the performance of Japanese organizations. Journal of Applied Psychology, 92: 10691083.

Truss, C. (1999). Human resource management: gendered terrain $\Delta$ International Journal of Human Resource Management, 10: 2, 180-200.

Shafer, W. E. Simmons, R S. (2008) "Social responsibility, Machiavellianism and tax avoidance: A study of Hong Kong tax professionals", Accounting, Auditing \& Accountability Journal, Vol. 21 Issue: 5, pp.695-720, doi: 10.1108/095135 70810872978

Wright PM, McCormick B, Sherman WS, McMahan GC. (1999). The role of human resource practices in petro-chemical refinery performance. International Journal ofHuman Resource Management, 10(4), 551-571.

Wright PM, McMahan GD, McWilliams A. (1994). Human resources and sustained competitive advantage: a resource-based perspective. International Journal of HumanResource Management, 5(2), 301-326.

Wright, P. M., \& McMahan, G. C. (1992). Theoretical perspectives for strategic human resource management. Journal of Management, 18: 295-320. 